\title{
Posterior Interosseous Nerve Entrapment in a Patient with Rheumatoid Arthritis
}

\author{
Romatoid Artritli Bir Hastada Posterior İnterosseöz Sinir Tuzaklanması \\ Korhan BAKLACI, ${ }^{1}$ Ahmet ÖZGÜL ${ }^{2}$ \\ ${ }^{1}$ Department of Physical Medicine and Rehabilitation, Isparta Military Hospital, Isparta, Turkey; \\ ${ }^{2}$ Department of Physical Medicine and Rehabilitation, TAF Rehabilitation and Care Center,
}

Gülhane Military Medical Academy, Ankara, Turkey

Posterior interosseous nerve entrapment is a rare complication of rheumatoid arthritis (RA), a chronic, systemic inflammatory disorder which principally involves the synovial joints. In this article, we present a case of posterior interosseous nerve lesion associated with rheumatoid synovial cysts of the elbow joint. According to literature survey our report is the first case in which posterior interosseous nerve entrapment was cured with a full recovery using conventional methods without any surgical intervention. This recovery was confirmed through imaging methods including magnetic resonance imaging, musculoskeletal ultrasound, and electromyography during 18-month follow-up.

Key words: Conventional therapy; electromyography; musculoskeletal ultrasound; posterior interosseous nerve; rheumatoid arthritis.

Rheumatoid arthritis (RA) is one of the etiological pathologies for mechanical entrapment of the posterior interosseous nerve (PIN). It is a chronic, systemic inflammatory disorder that may affect many tissues and organs but principally attacks synovial tissues and may cause neuropathies primarily of vasculitic origin. ${ }^{[1,2]}$ In addition, the inflammatory process causes synovial hyperplasia and effusion which, in turn, replaces or displaces other tissues. Moreover, compression of the neural tissues may ensue. ${ }^{[2]}$

The PIN is the distal branch of the radial nerve and has no cutaneous sensory innervation. Clinically,
Posterior interosseöz sinir tuzaklanması; temel olarak sinoviyal eklemleri tutan, kronik, sistemik inflamatuar bir hastalık olan romatoid artritin, oldukça nadir görülen bir komplikasyonudur. Bu yazıda, dirsek ekleminde var olan romatoid sinoviyal kist ile ilintili bir posterior interosseöz sinir lezyonu olgusu sunuldu. Bu olgu; posterior interosseöz sinir tuzaklanmasının, cerrahi bir girişim olmaksızın, konvansiyonel yöntemlerle tam bir iyileşme ile tedavi edildiği bilgimiz dahilindeki ilk rapordur. Bu iyileşme 18 aylık takip döneminde, manyetik rezonans görüntüleme, kas iskelet sistemi ultrasonografisi gibi görüntüleme yöntemleri ve elektromiyografi ile doğrulandı.

Anahtar sözcükler: Konvansiyonel tedavi; elektromiyografi; kas iskelet sistemi ultrasonografisi; posterior interosseöz sinir; romatoid artrit.

there is sparing of the radial-innervated muscles above the takeoff of the PIN during the entrapment. ${ }^{[3,4]}$ Thus, patients with a PIN lesion still may be able to extend their wrists, but only weakly, with a radial deviation. This is due to the relative preservation of the extensor carpi radialis longus (ECRL) along with a non-functional extensor carpi ulnaris (ECU) that is dynamically not balancing the action of the functioning ECRL and extensor carpi radialis brevis (ECRB) muscles. ${ }^{[3]}$ As the PIN innervates the extensors of the fingers and the abductor pollicis longus (APL), patients with a PIN lesion lose their ability for active

Received: January 20, 2012 Accepted: May 18, 2012

Correspondence: Korhan Baklacı, M.D. Isparta Asker Hastanesi Fiziksel Tıp ve Rehabilitasyon Kliniği, 32200 , Isparta, Turkey.

Tel: +90 532 - 3358331 e-mail: kbaklaci@yahoo.com

C2012 Turkish League Against Rheumatism. All rights reserved. 
digital extension at the metacarpophalangeal (MCP) joints of the second through fifth digits, including the thumb. This inability to extend the thumb is a useful distinguishing point when conducting a physical examination for differential diagnosis. ${ }^{[5]}$

\section{CASE REPORT}

A 72-year-old right-handed female who had had RA for five years and was being treated with oral methotrexate $(10 \mathrm{mg} /$ week) and indomethacine (75 mg/day) was admitted to our outpatient services with complaints of weakness in the fingers of her left hand and painful swelling in her left elbow This had started spontaneously two weeks before her admission. She did not have a history of trauma nor was she overusing or altering her medication. Physical examination revealed swelling at the left wrist and elbow along with a limitation in the range of motion in her left elbow of up to $30^{\circ}$ during extension and flexion, and the flexion and extension strength of the elbow were normal. She was unable to extend all of her left fingers, including the thumb (Figure 1). At the left MCP joints, extension strength was 2 out of 5 according to the Medical Research Council (MRC) scale of muscle strength. Cutaneous sensation was intact in both the upper and lower extremities, and there was no dislocation of the extensor tendons. Deep tendon reflexes were within normal limits. Mild radial deviation was observed during left wrist extension with a 4 out of 5 on the muscle strength scale. Extensor tendon rupture was excluded by the passive extension of the fingers during wrist flexion.

The laboratory analysis revealed a positive rheumatoid factor (RF), an elevated C-reactive protein

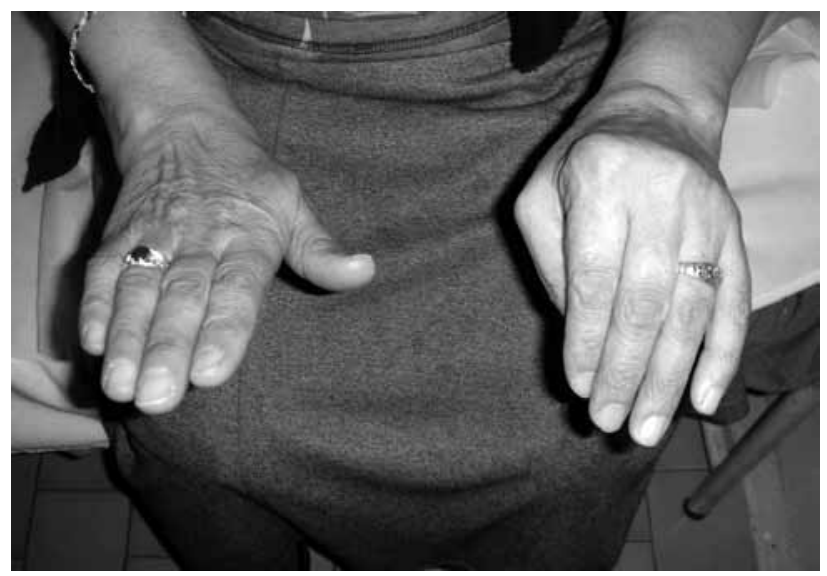

Figure 1. "Fingerdrop" Patient cannot extend the fingers on the left hand, including the thumb, at the MCP joint. level of $28 \mathrm{mg} / \mathrm{L}$, an erythrocyte sedimentation rate of $48 \mathrm{~mm} / \mathrm{h}$, and a normal leukocyte count of $7.2 \times 103 / \mathrm{mm}^{3}$. An electrophysiological evaluation revealed normal superficial radial sensory nerve action potential (SNAP) and latency $(15.01 \mu \mathrm{V}$ and $1.80 \mathrm{msec}$.$) . We obtained small amplitude (0.12 \mathrm{mV})$ from the extensor indicis (EI) muscle by stimulating the radial nerve in the groove between the biceps and brachioradialis. Radial compound muscle action potential (CMAP) may have technical difficulties in obtaining. ${ }^{[4]}$ Electromyography (EMG), which has been identified as the best technique with respect to localizing the lesion, ${ }^{[6]}$ confirmed normal motor unit potentials (MUP) with full recruitment from the left triceps, brachioradialis, ECRL, and ECRB as well as reduced recruitment with a variable degree of positive sharp waves and fibrillation potentials from the extensor digitorum communis (EDC), ECU, EI, APL, extensor pollicis longus (EPL), and extensor pollicis brevis (EPB) muscles. Electrophysiological findings revealed a typical PIN lesion.

Plain radiography of the left elbow, musculoskeletal ultrasonography (US), and magnetic resonance imaging (MRI) were used to make a visual representation of the pathology. The plain radiography showed soft tissue swelling with a normal articular surface. The US assessment $(7.5 \mathrm{MHz}$ linear transducer, gray scale, General Electric Medical Systems, Milwaukee, Wisconsin, USA) pointed out an "eye-shaped", demarcated, hypoechoic bulging mass with regard to articular effusion that was in close contact with the "contoured eyebrow-shaped" fascicular PIN. It had swelled to $2 \mathrm{~mm}$ compared

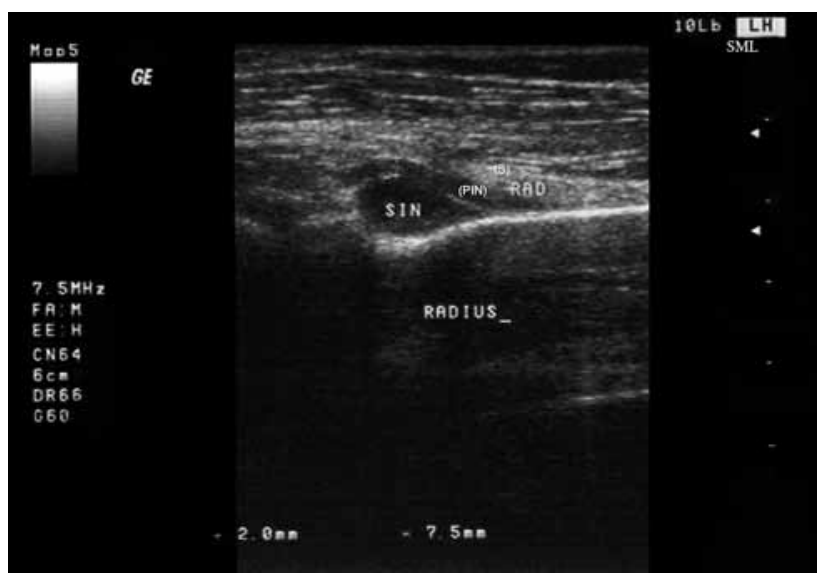

Figure 2. "Eye and eyebrow" Longitudinal ultrasonographic assessment of the left elbow demonstrates the close contact of the PIN and hypoechoic, demarcated synovial effusion (SIN) just proximal to the hyperechoic supinator muscle $(\mathrm{S})$, and anterior to the highly hyperechoic border of the radius bone. 

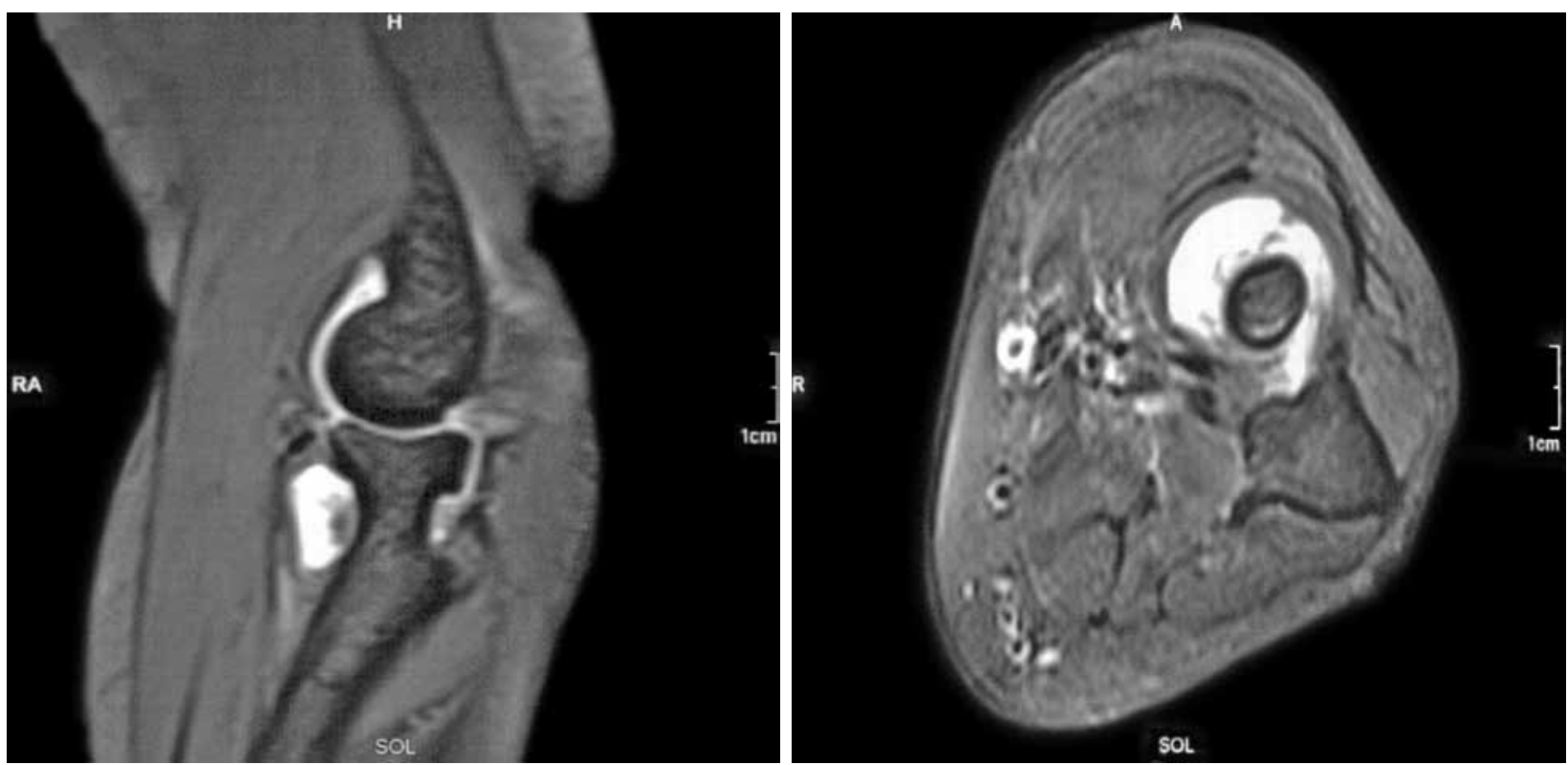

Figure 3. Axial fat-suppressed, sagittal gradient-echo T2-weighted images demonstrate effusion surrounding the radial head and displacing the supinator muscle.

with $1 \mathrm{~mm}$ on the asymptomatic right side (Figure 2). The MRI indicated hyperintense, demarcated fluid around the radial head, neck, and distal humerus (Figure 3).

The diagnostic approach, including a careful clinical examination, non-invasive imaging techniques (US, MRI), and electrophysiological assessment were sufficient to obtain the diagnosis of PIN palsy. The patient refused to be assessed surgically, so we reconsidered and rearranged her medication by increasing the methotrexate dosage to $15 \mathrm{mg} /$ week and also subcutaneously, drained the fluid and injected methylprednisolone acetate $(40 \mathrm{mg} / \mathrm{mL})$ intra-articularly by using the lateral approach to the center of the triangle formed by the lateral olecranon, the head of the radius, and the lateral epicondyle. ${ }^{[7]}$ The patient was followed up via clinical, US and electrophysiological assessments every three months. Her symptoms improved the second month after the injection, and they completely resolved at the sixth month without surgical intervention. The ultrasonographic resolution was noted at the third month, but better recruitment was obtained at sixth month from the affected muscles. However, fibrillation potentials remained albeit with a smaller amplitude size. Revisualization by MRI, repeated at the $18^{\text {th }}$ month, detected resolved effusion with clinical stability (Figure 4).

\section{DISCUSSION}

Rheumatoid arthritis is a chronic, systemic inflammatory disorder which has pathways such as exacerbations and remissions. Medications can reduce inflammation in the joints in order to relieve

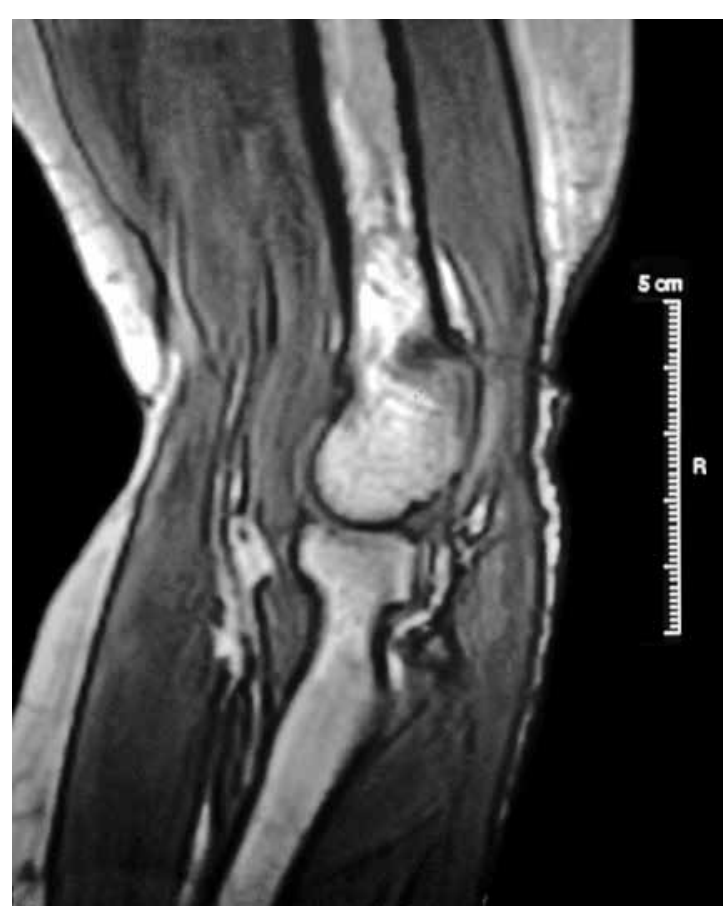

Figure 4. Coronal, fat-suppressed T2-weighted magnetic resonance imaging obtained after treatment shows resolution of effusion around the radial head. 
pain and prevent or slow joint damage. Although it mainly attacks synovial joints, both peripheral and central neurological consequences are observed in RA. Extraarticular, peripheral neurological manifestations may appear like compression neuropathies, for instance carpal tunnel syndrome (CTS), peripheral neuropathies, or mononeuritis multiplex as a consequence of vasculitis of the vasa nervorum. ${ }^{[2]}$ Vasculitic neural tissue involvement is seen, especially in systemic, long-lasting, seropositive RA patients. Although late emergence of vasculitic involvement and non-vasculitic involvement of neural tissues should be expected at any stage of the disease, a bulging mass due to synovitis and effusion may cause displacement and compression of neural or vascular tissues. Thus, any anatomical structure which lies immediately superficial to the capsule of the affected joint may be involved. In PIN palsy, a bulging mass due to chronic proliferative synovitis or acute/subacute synovial effusion of the elbow joint may cause compression of the PIN against the fibrous edge of the supinator muscle. ${ }^{[8]}$ Therefore, close monitorization of the inflammation and the clinical picture of RA patients is crucial so as to prevent complications like PIN palsy. Although PIN entrapment is a rare complication of RA, this palsy causes further disability by the partial loss of wrist and finger extension, which is necessary for daily living activities and self-care. Physicians who are devoted to the diagnosis and therapeutic treatment of rheumatic diseases should keep neural complications in mind and should remain aware of these potentially serious complications of RA.

A systematic literature search was conducted through November 2011, and only 21 reported cases of PIN palsy secondary to RA were described. ${ }^{[1,5,9-18]}$ Our patient may be the $22^{\text {nd }}$ case.

In the 21 cases we found, there was no consensus regarding the treatment of PIN palsy in RA, and no randomized controlled study was discovered that presented the efficacy of different treatment protocols. We were also not able to assess the effectiveness of conventional methods and compare them with the surgical option because of the complicated cases and the fact that some patients chose surgical treatment as a first protocol. Similar to Chan et al. ${ }^{[1]}$ we suggest that the apparent success of surgical intervention in the literature may be misleading. There have been only five cases of RA-related PIN palsy which have been treated successfully with conventional methods..$^{[1,5,11,18]}$ Systemic or intralesional steroids
DMARDs, biologics, and splinting have been reported to be successful. However, the long-term outcome in these reported cases has not been determined. Our report is the first case in which PIN entrapment was cured conventionally, the patient recovered fully without surgical intervention, and full resolution of the synovial cyst was correlated with imaging methods and EMG in the long-term. Most of the previous cases did not have any imaging techniques to prove effusion or other underlying pathologies. As in our case, US may be a practical, non-invasive diagnostic tool for evaluating patients with posterior interosseous entrapment. Without suppressing the activity of RA, even with successful surgery, regrowing of the remnant synovial tissue and reflux of synovial fluid may complicate the situation.

As mentioned above, vasculitic neuropathy is another rare complication as an underlying etiology of PIN palsy in RA. Chan et el. ${ }^{[1]}$ suggested that EMG accompanied by a nerve conduction study (NCS) may be able to distinguish between vasculitic and compressive lesions, and they claim that the evidence of axonal regeneration can be seen in vasculitic lesions but not in compressive lesions. They also describe the excellent response with medical treatment in vasculitis-related PIN palsy. However, EMG alone is not sufficient for being able to be conclude that the underlying problem is vasculitis. Furthermore, pathological investigation through biopsy is important. According to Preston and Shapiro ${ }^{[3]}$ the common pattern is demyelination in the entrapment neuropathies, such as CTS radial neuropathy at the spiral groove, and peroneal neuropathy at the fibular neck, but it is not seen in the non-localizing ulnar neuropathy. The most likely lesion is at the elbow in most patients, and ulnar conduction studies simply show evidence of axonal loss without slowing or conduction block across the elbow. ${ }^{[6]}$ Therefore, only demyelination and axonal loss can be ruled out to describe the underlying etiological pathology. Even the previous surgery itself may cause these EMG findings in their study. ${ }^{[1]}$

In conclusion, in RA patients with uncontrolled inflammatory activity, complaints regarding the peripheral neurological system should be screened further to rule out possible compressive or vasculitisrelated neuropathies. Compressive neuropathies caused by synovial cysts can be treated with either surgical or conservative methods. Every RA patient with PIN palsy should undergo conservative treatment 
methods before they develop irreversible neural changes. Surgical treatment should be considered in patients who failed to improve after a reasonable period of conventional treatment, but it should be kept in mind that inappropriate treatment may once again cause space-occupying pathologies.

\section{Declaration of conflicting interests}

The authors declared no conflicts of interest with respect to the authorship and/or publication of this article.

\section{Funding}

The authors received no financial support for the research and/or authorship of this article.

\section{REFERENCES}

1. Chan JK, Kennett R, Smith G. Posterior interosseous nerve palsy in rheumatoid arthritis: case report and literature review. J Plast Reconstr Aesthet Surg 2009;62:e556-60.

2. Birrell FN, Isaacs JD. Extraarticular manifestations of rheumatoid arthritis. In: Koopman W, Moreland LW, editors. Arthritis and allied conditions 15th ed. Philadelphia: Lippincott Williams and Wilkins; 2005. p. 1195-205.

3. Preston DC, Shapiro BE. Radial neuropathy. In: Preston DC, Shapiro BE, editors. Electromyography and neuromuscular disorders. Philadelphia: Elsevier; 2005. p. 327-42.

4. Dumitru D, Zwarts MJ. Focal peripheral neuropathies. In: Dumitru D, Amato AA, Zwarts MJ, editors. Electrodiagnostic medicine. 2nd ed. Philadelphia: Hanley \& Belfus; 2002. p. 1043-126.

5. Fernandez AM, Tiku ML. Posterior interosseous nerve entrapment in rheumatoid arthritis. Semin Arthritis Rheum 1994;24:57-60.

6. Preston DC, Shapiro BE. Clinical-electrophysiological correlations: Overview and common patterns. In: Preston DC, Shapiro BE. editors. Electromyography and neuromuscular disorders. 2nd ed. Philadelphia: Elsevier; 2005. p. 233-51.
7. Simon LS. Therapeutic injection of joints and soft tissues. In: Crofford L, Klippel JH, Stone J, Weyand CM, editors. Primer on the rheumatic diseases. 12th ed. Atlanta, GA: Arthritis Foundation; 2001. p. 579-91.

8. Spinner M. The arcade of Frohse and its relationship to posterior interosseous nerve paralysis. J Bone Joint Surg [Br] 1968;50:809-12.

9. Westkaemper JG, Varitimidis SE, Sotereanos DG. Posterior interosseous nerve palsy in a patient with rheumatoid synovitis of the elbow: a case report and review of the literature. J Hand Surg Am 1999;24:727-31.

10. White SH, Goodfellow JW, Mowat A. Posterior interosseous nerve palsy in rheumatoid arthritis. J Bone Joint Surg [Br] 1988;70:468-71.

11. Millender LH, Nalebuff EA, Holdsworth DE. Posterior interosseous-nerve syndrome secondary to rheumatoid synovitis. J Bone Joint Surg Am 1973;55:753-7.

12. Marmor L, Lawrence JF, Dubois EL. Posterior interosseous nerve palsy due to rheumatoid arthritis. J Bone Joint Surg [Am] 1967;49:381-3.

13. Chang LW, Gowans JD, Granger CV, Millender LH. Entrapment neuropathy of the posterior interosseous nerve. A complication of rheumatoid arthritis. Arthritis Rheum 1972;15:350-2.

14. Velazco A. Three cases of posterior interosseous nerve palsy in long-standing rheumatoid arthritis. Ortop Rev 1982;9:109-13.

15. Ishikawa $\mathrm{H}$, Hirohata $\mathrm{K}$. Posterior interosseous nerve syndrome associated with rheumatoid synovial cysts of the elbow joint. Clin Orthop Relat Res 1990;254:134-9.

16. Minami M, Kato S, Kondo M, Funakoshi T. Posterior interosseous nerve palsy secondary to rheumatoid cyst of the elbow joint: case report. Mod Rheumatol 2004;14:191-5.

17. Ogawa H, Akaike A, Ishimaru D, Yamada K, Shimizu T, Koyama Y, et al. Posterior interosseous nerve palsy related to rheumatoid synovitis of the elbow. Mod Rheumatol 2007;17:327-9.

18. Malipeddi A, Reddy VR, Kallarackal G. Posterior interosseous nerve palsy: an unusual complication of rheumatoid arthritis: case report and review of the literature. Semin Arthritis Rheum 2011;40:576-9. doi: 10.1016/j.semarthrit.2010.07.011. 